University of Nebraska - Lincoln

DigitalCommons@University of Nebraska - Lincoln

1987

\title{
The Assault on Assimilation: John Collier and the Origins of Indian Policy Reform
}

Henry E. Fritz

St. Olaf College

Follow this and additional works at: https://digitalcommons.unl.edu/greatplainsquarterly

Part of the Other International and Area Studies Commons

Fritz, Henry E., "The Assault on Assimilation: John Collier and the Origins of Indian Policy Reform" (1987). Great Plains Quarterly. 332.

https://digitalcommons.unl.edu/greatplainsquarterly/332

This Article is brought to you for free and open access by the Great Plains Studies, Center for at DigitalCommons@University of Nebraska - Lincoln. It has been accepted for inclusion in Great Plains Quarterly by an authorized administrator of DigitalCommons@University of Nebraska - Lincoln. 
The Assault on Assimilation: John Collier and the Origins of Indian Policy Reform. By Lawrence C. Kelly. Albuquerque: University of New Mexico Press, 1983. Appendix, notes, index. xxix +445 pp. $\$ 23.50$.

About one quarter of this book is devoted to John Collier's interest in various kinds of social experiments before he discovered the American Indian. One learns a great deal about Collier's family background and his association with Mabel Dodge, Stella Atwood, Tony Luhan, Dr. John R. Haynes, and D. H. Lawrence. No additional research will be needed in reference to these aspects of Collier's reform impulse and orientation.

For the reader who wishes to be informed about the origins of the debate over the Bursum Bill and the substitute measures that led to the creation of the Pueblo Lands Board in 1924, it would be difficult to find a better source. The same is true of the particulars associated with the organization and financial difficulties of nurturing the early growth of the American Indian Defense Association. And the main features of the religious freedom issue in relation to Commissioner Charles Burke's circular and message on Indian ceremonial dances are adequately treated.

However, Lawrence Kelly has not dealt satisfactorily with the broad question of reform of Indian policy and administration during the 1920s. He is mistaken in stating that the main features of cultural pluralism were not "explicit in the spring of 1923, even to most of Collier's supporters" (p. 250). Critics of Burke's dance message stressed that Indians should be allowed to maintain their "distinct community life" and their traditional "social and religious usages." During the debate over the Omnibus Bill, Helen Hoy Greeley and Francis C. Wilson argued for perpetual tribal membership and continued federal guardianship over all Indians, both competent and incompetent, in a joint statement as counsels of the American Indian Defense Society and the Eastern Association on Indian Affairs. And in December 1922, the American Association for the Ad- vancement of Science and the American Anthropological Association unanimously passed a resolution consisting of six points, several of which suggested cultural pluralism and the direction of future Federal Indian policy.

Kelly is also mistaken in writing that, "The Council of One Hundred proved to be the last stand of the assimilationist forces that had significantly influenced government policy since the late nineteenth century" (p. 293). Actually 1923 was a watershed year in which cultural pluralists first challenged the advocates of forced assimilation, who remained dominant at least until the end of the decade. If any particular meeting was a last stand of assimilationists, a better choice is the Lake Mohonk Conference of October 1929. The assimilationists were even more dominant there than at the Interior Department auditorium in December 1923. Also Kelly's factual information on the Council of One Hundred is flawed. He gives an attendance figure of sixty (p. 288), whereas the official roll call indicates sixty-seven.

The last chapter of the book is the most disappointing. After recognizing in an earlier chapter that Collier regarded himself as a propagandist, Kelly seems to have been influenced by the portrait of Charles Burke that Collier's organization implanted in the public mind. Kelly fails to acknowledge that Collier's main interest was in driving Burke, Edgar Meritt, and Hubert Work from office on the premise that this was necessary before Indians could receive justice. Statements that Burke was sincere but on the wrong side fail to recognize that Burke was doing his very best to improve conditions on the reservations and to protect Indian interests within the context of assimilationist philosophy and the political realities of the 1920s. The statement that "the Indian Office lacked any concept of a preventive health-care program" (p. 373) ignores the health drive that Work and Burke undertook from 1923 forward with the help of the United States Public Health Service. There is no recognition that the Indian Office was trying 
to make progress with insufficient appropriations, having inherited a disgraceful situation owing to neglect of the reservations during World War I and during the budget conscious Harding administration.

Finally, there is no treatment of the origins of the Meriam Report in this volume, nor is there recognition that Collier was interested in a survey of conditions on reservations mainly for the purpose of discrediting the Bureau of Indian Affairs. Collier's role in seeking a Congressional investigation through James Frear of Wisconsin in 1926 is neglected, as are his relations with Senator William King of Utah, whose resolution created the Senate Subcommittee to Investigate Indian Affairs on 1 February 1928. The closing paragraph of the book says:

"In 1927 [1928] the Brookings Institution released the report that Secretary Wilbur [Work] had commissioned after the meeting of the Council of One Hundred. ... That same year Collier persuaded his newly found supporters in the U.S. Senate to create a subcommittee to conduct its own investigation of Indian affairs and he then proceeded to direct the subcommittee's work." (p. 377)

Hopefully this topic will be treated in more depth and with greater accuracy in the proposed volume two of this study.

HENRY E. FRITZ

Department of History

St. Olaf College 